\title{
Transformation from Class Banking to Mass Banking through Inclusive Finance: A Paradigm Shift
}

\author{
Ipseeta Satpathy ${ }^{1}$, B. Chandra Mohan Patnaik $^{1} \&$ Pradeep Kumar Das $^{1}$ \\ ${ }^{1}$ Professor, School of Management, KIIT University, Bhubaneswar, Odisha, India \\ Correspondence: B. Chandra Mohan Patnaik, School of Management, KIIT University, Bhubaneswar 751024, \\ Odisha, India. Tel: 91-966-822-4322. E-mail: bcmpatnaik@ksom.ac.in
}

\author{
Received: April 5, 2013 Accepted: August 5, 2014 Online Published: September 29, 2014 \\ doi:10.5539/ass.v10n19p11 URL: http://dx.doi.org/10.5539/ass.v10n19p11
}

\begin{abstract}
The strategies of rural transformation in India focused on improving the standard of living of rural population has undergone several changes keeping in view the mammoth size of population, its changing dynamics and socio -cultural diversities of our country But the economic stagnation of vast chunk of rural population still suffers from social and financial exclusion resulting with high incidence of poverty, rising unemployment, growing inequality along with rich-poor divide widening. The high growth story of our country in the post reform era is not broad based, regionally imbalanced and socially inequitable Indian Banking industry in conformity with national policy objectives has reoriented from Class Banking to Mass Banking approach to enhance its outreach to bring the marginalized and excluded population into its fold for mainstream economic activity. The branch expansion was accelerated and institutional credit flow to poor rural households reached new heights to relieve them from the clutches of usurious informal money lenders. Modern banking in India has leveraged IT driven initiatives to bring the excluded population into the fold of mainstream banking, develop new products to suit their needs and more importantly educate them on financial products and services to enable them to take informed decisions. The Institutional mechanism, for enhancing access to institutional credit have been strengthened by establishing pro-poor institutions like Regional Rural Banks (RRBs) and National Agricultural Bank for Agricultural and Rural Development (NABARD) etc. The business delivery models like Self Help Groups (SHG)-Bank linkage programme, and Micro finance institutions have been encouraged to provide microfinance services at doorstep of marginalized households. The Agent/Correspondent Banking model of commercial Banks have been given a big boost to provide wide access of low income/marginalized people to Financial Markets. Financial inclusion being a gigantic task, it calls for an appropriate and well-coordinated/collaborative strategy by all the stake holders involved in its implementation. The government needs to increase investment in economic and social capital by increasing investment in basic rural infrastructure Banking system is poised to provide efficient economic infrastructure like savings, access to easy credit and robust payment system. The community based organizations/NGOs should catalyze local participation to enhance efficiency and transparency in delivery of financial services to common man for making inclusive growth a reality.
\end{abstract}

Keywords: financial inclusion, social exclusion, SHG-Bank-linkage, class banking, mass banking, agent/correspondent banking

\section{Introduction}

In the post-independence period spanning across six decades of poverty reduction and measures to address social exclusion have been the central agenda of socio-economic development initiatives of the government as well as a matter of political discourse. Although economic growth of our country was in high growth trajectory and reckoned as one of the fastest growing economy in the world, still we carry one third of the world's poor. There is wide variation in development across states and growing schism in rural -urban divide. Providing access to a bundle of financial services needed by excluded people in fair and transparent manner has become a national commitment and public policy priority since $11^{\text {th }}$ Five year plan commencing from 2005-06.Economic development and growth of the financially excluded is a means to achieve the objective of improved living standards and well-being. Financial inclusion is a critical factor for inclusive growth and development of the country. It encourages expansion of outreach of rural bank branches in unbanked centers, innovative financial 
services/products with focus on affordability, popularizing the Business correspondent /Business Facilitators model, and relaxed Know Your Customer (KYC) norms for improving access to a bouquet of financial services and remittance/payment system through Direct Benefit transfers. But still, a significant proportion of the households remained out of the ambit of the formal financial system. As per some empirical studies around $40 \%$ of people in our country have no access to the most basic financial services which warrants extending the outreach to vast unbanked/underserved population of approximately 700 million dwelling in six lakh villages, is a stupendous and uphill task.

It is now being increasingly felt that the low income people are commercially viable this proposition has attracted the attention of the Indian Banks. The formal financial institutions have an important role in attaining the objective of inclusive growth, not as a social compulsion, but as an emerging business proposition.

Inclusive Financial Policies and practices are also popular in developed economies. In US Community Reinvestment Act (1997) prohibits banks from any sort of discrimination to low and moderate income groups for accessing credit and other financial services in the area of operation. In France, the Law on Exclusion (1998) confers an individual's right to possess a bank account and in case of refusal to any individual, he may approach the Bank of France who will identify an institution to provide a bank account. In South Africa, the central Bank of the country had launched a low cost bank account for financially excluded people in 2004. In UK, a Financial Inclusion Task Force was constituted by the government in 2005 to increase access to banking and affordable credit with free advice on monetary matters.

\section{Objective of the Study}

Through this paper a sincere endeavour has been made to analyse the social banking perspectives of Indian Banks in post nationalization era in expanding outreach and deepening the access to each rural household rank and file effectively and without any discrimination. Broadly the objective covers:

1. To discuss the contextual aspects of bank-led Financial Inclusion and its relevance to underprivileged segments for enhancing access to financial services.

2. To evaluate the role of banks in providing access to vast segment of marginalized people through social banking initiatives for broad basing growth with equity.

3. To suggest measures to increase the effectiveness of the Financial Inclusion implementation plans of Banks for financial empowerment of the excluded segment.

\section{Methodology}

The secondary sources of publications from various journals, newspapers, different books on the subject and related websites have been referred for arriving at the findings of this study.

\subsection{Limitations}

Since the study is based on secondary source, the observations are more generalized in nature and may not be applicable to specific category of targeted segment of vulnerable people. Moreover the discussion covers only the recent initiatives taken by Indian banks for promoting inclusive financial system and all the social banking strategies since post-independence have not been factored

\subsection{Why Financial Inclusion}

The reasons attributed for having failed to adequately reach large number of low income and poor households by mainstream banking institutions as observed by the Khan Committee (2005) includes socio-economic factors such as lack of outreach of bank branches to last mile of population, higher transaction costs and unreasonably long time taken for banking transactions, long distance of bank branches, inability to provide any collaterals, perception that poor are not bankable since having no regular income, poverty, illiteracy, poor infrastructure in rural areas, easy availability of loans from informal lenders etc.

In addition to these other factors such as geographical factors like sparse population, lack of cost effective technology to integrate with Core Banking System (CBS), inadequate banking products etc also contributes significantly for the exclusion of the poor and low income population The suffering masses who are excluded from the mainstream economic activity are the low income households like landless and marginal farmers, urban slum dwellers, senior citizens and women, migrants and oral lesses (cultivating land without any ownership) etc.

\subsection{Defining Financial Inclusion}

In essence Financial Inclusion means providing banking services at affordable cost to disadvantaged and low-income people which includes access to savings, credit, insurance, payments and remittance facilities and 
other financial services. In his budget speech of 2005-06, P. Chidambaram, Hon'ble Finance Minister underscored the need for Financial Inclusion of the excluded population at the bottom of the pyramid as an emerging business opportunity for the Indian Banking Sector.

According to Rangarajan Committee, products In brief Financial Inclusion means providing unrestrained and effective access to all who tend to be excluded for improving quality of life and ensuring a decent standard of living

\subsection{Consequences of Financial Exclusion}

Financial Exclusion has serious implications among low-income households owing to lack of access to credit facility which result in low savings and investments ; lack of financial planning and financial security to absorb any shocks, constraints in gaining access to credit from formal sources due to flexibility of informal sources for easy access to credit at usurious rates, dampen entrepreneurial spirit of masses countryside due to non-availability of timely and adequate credit from formal sources, leakages in getting direct benefit transfer schemes of social welfare, etc. All these deleterious effects cumulatively result in downward slide of economic growth of the country in general.

Other implications of exclusion result in low clientele base for small business, limited options to use costly and informal channels for remittance of money etc In totality we may say that Financial Exclusion not only widens the 'Rural-Urban gap ', but also leads to 'Social Exclusion'.

\subsection{Extent of Exclusion}

As per the NSSO (60th round) data, Uttar Pradesh, Bihar and Jharkhand constitutes about $27 \%$ of the country's population but it is amazing that $41 \%$ of the Indian poor reside in these three states The deplorable state of affairs can be gauged when we find that out of a total of 89.3 million farmer household45.9 million farmer households constituting 51.4\%any do not have access to credit, either from formal or informal sources.

According to World Findex Survey in 2012, only 35\% of adult Indians have access to formal bank accounts, $8 \%$ rural population to credit, $2 \%$ people access to remittance facilities, and $4 \%$ population receive payments/settlements from govt.

The above statistics calls for the priority to be accorded to financial inclusion agenda to bring the people at the Bottom of the pyramid to the ambit of formal financial system for availing the benefits and improve living condition

\subsection{Objectives of Financial Inclusion}

Financial landscape of the country has become increasingly complex arising out of globalization, technological advancements; inter play of market forces and financial innovation. Bank nationalization in 1969 has shifted the focus from class banking to mass banking. Retail banking has taken the center stage for broad basing the portfolio of banks from traditional to class banking. Class banking was aimed at providing the benefits of economic growth and development /financial services to upper segment being super included while the excluded segment were deprived of the benefits of development and were not provided the basic where withals for income generation through productive employment thus keeping them trapped in the vicious cycle of poverty. This accentuated the rural-urban divide and inter-state disparity in a greater way and the national commitment of growth with equity remains unrealized. Thus in order to percolate the benefits of planned development and growth for the people at the grass root level the policy focus of the Indian planners shifted to bring the marginalized people to mainstream economy for the social and economic empowerment

Rural income has grown significantly as evidenced by the growing consumption pattern which is more than urban population between 2009-10 and 2011-12. To seize the emerging business opportunities, Indian banks have realigned their policies to fulfil the aspirations of the rural population. The era of consumerism has ushered in, various types of other services like remittance needs to be met by banks through modern payment system, thanks to the availability of various retail loans like personal loans, car loans, educational loans and housing loans etc. All these process would culminate in manifold growth of bank's business. Thus Financial Inclusion is a win-win situation for both banks and hitherto for underserved population

Financial Exclusion has traditionally been the public policy focus which focuses on supply side measures of financial services to connect unbanked/underserved people to formal banking system while demand side perspectives should also be accorded due priority by providing financial literacy and education to the poor illiterate masses. The financial literacy initiative should move hand in hand with financial inclusion agenda for improving access to financial services as well as ensuring its usage for the low income people at large. 
The key objectives of inclusive finance includes bringing the low income people to the fold of formal banking system, increasing financial awareness to empower the low income people for making informed financial decisions and reduce exploitation of the poor from informal money lenders. The initiative through bank-led model includes four types of banking products like a savings product with inbuilt overdraft facility, a pure savings product i.e recurring deposit product, a remittance product for Direct Benefit Transfer and other remittances and entrepreneurship credit in the form of Kisan Credit Card (KCC) and General Credit Card (GCC).

\section{Financial Inclusion and Initiative of Indian Banks}

Banks have played a key role in the economic development process of our country particularly in rural areas. It is being increasingly recognized that poor are bankable and rural sector is poised for tremendous growth with increase in business volume in rural markets in recent years. With the launch of five year plans our planners have experimented with various alternatives to reach the poor segments for providing greater access to financial services, primarily access to credit, since last six decades for ensuring equitable growth. The measures include multiagency approach to meet the credit needs of the poor which focused on institutional framework like revitalising cooperative credit delivery system followed by nationalization of the major public sector banks in 1969and 1981 and also establishing Regional Rural Banks (RRBs). Simultaneously, several measures including launching of the Lead Bank Scheme, targeted lending for the Priority Sectors, SHG- Bank linkage launched by NABARD in 1992 followed by Reserve Bank of India (RBI)'s support at later stage which has ushered in a Microfinance revolution in the country to meet the financial needs of low income people in rural area, the Service Area Approach, the SHG-Bank linkage programme and introduction of the Kisan Credit Card (KCC) and General Credit cards(GCC), etc. were some of the glaring and significant initiatives taken so far to bring the excluded to mainstream economy. Various innovative banking products leveraging the advancement of information \& communication technology have been key enabler to increase the coverage of the poor /unbanked population into the fold of the formal banking system In spite of all these efforts and policy initiatives, a vast segment of the population residing in the rural India are deprived of minimum banking services. Thus, there is no denying to the fact that social exclusion of the people in general is no doubt large, it also varies significantly across states, social groups and asset classes. The economic backwardness is directly linked to magnitude of exclusion

\section{Institutional Initiatives}

Bank led model has been adopted since banks are equipped with necessary resources and infrastructure and capability for investing in technological up gradation for leveraging the same for benefit of rural poor. In addition non-bank Micro Finance Institutions (MFI) has also been permitted to supplement the efforts of banks. For scaling up the banking operations in unbanked centers and making it more sustainable, the commercial aspects of the inclusion model are also being explored through bundling of financial services with credit. Towards this end banks are exploring the new delivery models and innovative products and services to cater to the needs of the underprivileged sections financial literacy being an integral part of Financial Inclusion initiative to stimulate demand, a national strategy for financial education for rural people under the aegis of Financial Development Council (FDC) has been formulated. RBI has also extended supportive role by creating regulatory environment and institutional support to Banks like Financial Inclusion Advisory committee constituted at RBI with active support of State Level Bankers Committee (SLBC) and 659 Lead District Managers (LDM) across the country. Rural Self Employment Training Institutes at each districts are working towards capacity building for self-employment ventures and 700 financial literacy centers have also been activated to support the inclusive agenda.

\section{Other Initiatives for Mass Banking}

The major initiatives for building an inclusive financial system have emanated from regulatory authorities, governments and the banking industry. To address the problem of exclusion and increasing the depth and outreach to unbanked centers of the country as a strategy of mass banking, banks have migrated to Core Banking System (CBS) platform for facilitating real time transactions and increased offerings of IT based solutions like ATM cards, mobile banking, and agent banking through hand held devices have been operationalized. KYC procedures have been simplified and basic banking, no frill accounts have been encouraged in mass scale which will facilitate Direct Benefit Transfer (DBT) of low income people under various welfare schemes at low cost and without leakages. Microfinance initiatives through SHG-Bank linkage have also evolved over the years since 1992 as a flagship microcredit programme which has contributed significantly to accelerate the inclusive and equitable growth process by delivering financial services to poor in a cost effective manner. In order to streamline the credit delivery and other services by Non-Banking Financial Companies (NBFC) - Micro Finance Institutions 
(MFI), RBI has enforced regulated code of conduct for client protection which would insulate operational risk by MFIs for greater Financial Inclusion.

The effective linkage of business correspondents between banking network and unreached clients has become a major objective which has been operationalized in large scale for channeling banking products to vast segment of unbanked population that may give a big push to the inclusive growth process.

\section{Role of IT}

To facilitate financial inclusion process and ensure wide access of common masses to formal banking and financial services, ICT (Information and Communication Technology) has become a key enabler and friendly tool to support the illiterate customers in cost effective way. ICT solutions to banking transactions has been widely hailed as Banking at Doorstep for the poor which minimizes not only the cost of banking transactions but also reduces the time and money required for accessing banking services. The centralized banking operations, network based computing, ATMs, internet banking, smart card based products etc have all contributed to popular strategy to promote mass banking.

\section{Challenges to Financial Inclusion}

Although a number of initiatives have been undertaken by Government, regulators and banks for universal financial access to all, some of the factors that inhibit the progress relate to lack of conviction on the part of bank's top management for considering financial inclusion efforts as a commercial proposition rather as a social obligation this limits the effectiveness of the programme. Several business models have been put to use by banks, but no single model has yet been stabilized and proved to be universally acceptable with tested efficiency for further scaling up the model.

Meantime access to financial services of unbanked/excluded population in rural India has improved since FI implementation plans were rolled out in 2010-11. This envisaged covering all unbanked villages above population 2000 and covering outreach to less than 2000 population as per bank's board approved plans. The actual usage of banking transactions in basic savings bank accounts are not encouraging although 2.70 lakh outlets of business correspondents are available across the country which indicates the potential benefits of financial access to unbanked masses could not be effectively accrued. This has put a question mark on the viability and sustainability of the efforts for inclusive growth. The ICT solutions for reducing cost of delivery of financial services have not been effectively performed due to lack of proper connectivity in rural areas.

\section{Recommendations}

There is no single comprehensive indicator to assess the extent of inclusion of the underprivileged in Indian context. A multi-pronged and diversified approach is the crying need of the moment to eliminate exclusion and realize the national objective of equitable and sustainable growth with wider participation of the community as a whole. The following innovative measures would facilitate the inclusive growth process to be more effective and meaningful.

(1) Financial awareness being a key element for opening and keeping the accounts operational is an integral part of the inclusive process which needs to be popularised for self-management of money.

(2) Comprehensive board approved plans to cover all unbanked villages through a judicious mix of brick-mortar branch and branchless banking should be operationalized co-terminus with regulatory directions.

(3) The Agent Banking model presently at nascent stage should be properly supported by base branches of Indian banks for easy documentation and prompt redressal of grievances of underprivileged people in general

(4) Providing adequate infrastructure like power supply and physical connectivity at rural locations with a proper coordination and interaction among the stake holders would provide a great impetus to commercial aspects of the initiative for up scaling and greater sustainability.

(5) Through product innovation and improved /simplified delivery model of banking services to common man, the transaction cost can be further minimised through ICT based solutions. Ensuring appropriate and affordable service to the needy.

(6) Sound planning and proper coordination between two major pillars i.e. government and banks will help in realising the stated goal of connecting with the unreached.

(7) Proper selection of unbanked /under banked areas and selection of financially excluded, but not the ones already included should be the guiding principle of increasing the outreach 
(8) Not only opening of the basic savings account but ensuring the usage of the accounts by undertaking regular transactions to keep the accounts operative is an important parameter to be reckoned with.

(9) Right attitude and positive mindset is a pre-requisite for the operating banking staff as well as agents appointed under Business Correspondent (BC) model to reap rich dividend of building inclusive financial system.

(10) Greater collaboration among various implementing agencies is an essential requirement to mitigate risks, preventing mis-selling and ensuring business continuity and disaster recovery in the operations.

\section{Way Forward}

The transformation of Indian banking landscape from class to mass banking is a path breaking initiative of government and regulators by opening its door to excluded population. Towards realizing the goal of economic empowerment of marginalized segment, there is a need to integrate financial inclusion and financial literacy for leveraging the benefits of financial access as well as its improved usage.

The national mission of attaining inclusive growth with financial stability is a critical component which will remain ambitious without a well-coordinated and active participation of all the stakeholders involved in implementation of the policy. In the light of the experience of the developed economy, we may accept the proposition that financial inclusion propels economic growth. All efforts must be made to remove the bottlenecks in implementation process and expedite the same for achieving the goal of inclusive growth on priority basis financial Inclusion must be a step ahead of banking inclusion. To sum up, India needs to travel the road of Financial Inclusion more aggressively in a planned and structured manner to emerge as a global player.

\section{References}

Chakrabarty, K. C. (2011). Deputy Governor, RBI, Financial Inclusion: A road India Need to Travel. Speech Delivered on October 12, 2011.

Chakrabarty, K. C. (2013). Deputy Governor, RBI, Financial Inclusion in India, Journey So far and way Forward. Speech Delivered on September 6th, 2013.

Leeladhar, V. (2005). Taking Banking Services to Common Man-Financial Inclusion, RBI Bulletin, January 2006. Speech Delivered on December 2nd, 2005.

Nili, K., \& Deminent, K. (2012). Measuring Financial Inclusion the Global Findex data base.

Ramakrishna, R. (2012). Financial Inclusion: Road Ahead. Bank Quest. The Journal of Indian Institute of Banking and Finance, 83, 41 \& 43-45.

Ranagarajan, C. (2008). Report of Committee on Financial Inclusion. Ministry of Finance Govt of India, Feb 5th, 2008.

Report on Trends and Progress of Banking in India, RBI. June 30, 2012. (FY2011-12).

Srinivasan, N. (2012). Financial Inclusion framework-Is it Inclusive: Bank Quest. The Journal Of Indian Institute of Banking and Finance, 83, 38.

Sujatha, B. (2007). Financial Inclusion, Concepts, Strategies (1st ed.). ICFAI University Press.

Tansale, M. V. (2012). Financial Inclusion and FLCC: Bank Quest. The Journal Of Indian Institute of Banking and Finance, 83, 19-20.

Thorat Usha. (2006). Financial Inclusion and Millennium Development Goals, RBI Bulletin, February, 2006. Speech Delivered on Jan 16th, 2006.

Venugopalan, P. (2012). Fiancial Inclusion-Forward Step for Microfinance Sector: Bank Quest. The Journal of Indian Institute of Banking and Finance, 83, 30.

\section{Copyrights}

Copyright for this article is retained by the author(s), with first publication rights granted to the journal.

This is an open-access article distributed under the terms and conditions of the Creative Commons Attribution license (http://creativecommons.org/licenses/by/3.0/). 